\title{
Islam and Peace
}

\section{A. Muqtedar Khan}

February 6-7, 1998. Sponsored by Nonviolence International and the Mohammad Said Farsi Chair of Islamic Peace at The American University, Washington, DC.

At a time when the Muslim world is suffering from an unmitigated epidemic of violence, both from within and from without, Muslim scholars and peace and social activists got together for two days to examine the Islamic tradition of peace and to explore strategies to once again realize this Islamic ideal. The conference consisted of over 25 panelists with nearly 75 attendees in the audience. For reasons not divulged, the conference was closed and attendance was by invitation only. The hosts, Mubarak Awad and Karim Crow of Nonviolence International and Abdul Aziz Said, the Mohammed Said Farsi Professor of Islamic Peace at American University, were very gracious and managed to put up an excellent show that was reminiscent of the hey days of Islamic civilization. In a land so far away from the Islamic heartland, for two days, the conference reproduced a feeling that once again the world was under the merciful and benign shadow of Islamic traditions.

The conference had an unusual format. Only a few of the participants were invited to present papers on subjects that dealt with the meaning of peace in Islam, the barriers to peace in the Muslim world, and the tensions between heightened religious identity and violence. The rest of the panelists acted as discussants who contributed their own perspectives on the subject. The audience was allowed extended time to interact with the panel. The conference consisted of two keynote addresses - one on each day-by Seyyed Hossein Nasr (Professor of Islamic Studies at George Washington University) and Seyyeda Rabab Sadr Chareffedine (Chairperson of Imam Al-Sadr Foundation of Lebanon). However, Seyyeda Rabab Chareffedine could not make it, instead her son Raed read her speech.

The participants came from the Muslim world as well as the West. Maulana Waheeduddin came from India, Jawadat Sa'id came from Syria, Laith Kubba from London, Sakeena Yakoobi from Afghanistan, Kamal Hassan from Malaysia, Mokhtar Lamani represented OIC, Su'ad al-Hakim from Lebanon, Mehmet Ersoy from Turkey and Ambassador Sadek Sulaiman from Oman. The American contingent consisted of M.

M. A. Muqtedar Khan is a Doctoral Fellow in International Relations at Georgetown University. 
Nimer of American University, Mahmood Ayub of Temple University, Suhail Hashmi of Mt. Holyoke College, Azizah Al-Hibri of Richmond University, Abdullah an-Naim of Emory University, Sulayman Nyang of Howard University, Michael Salla of American University, and M.A. Muqtedar Khan of Georgetown University.

Many organizations were represented on the panel. Seyyed Sayeed of Islamic Society of North America, Saleh Saleh of American Muslim Council, Yahya Muhaimin from the Indonesian Embassy, Ghulam Nabi Fai of the Kashmir American Council, Mary Jane Deeb of Middle East Journal, and Mahnaz Afkhami of Sisterhood is Global Institute. This list of participants includes only the panelists who actually participated in discussions and made brief presentations/comments on the four papers discussed. Imam Wahid Abdurrahman, the leader of Nahdatul Ulema of Indonesia, was also invited to read a paper, but unfortunately his health prevented him from traveling, so, out of respect for the ailing scholar, Hashmi summarized one of his earlier writings.

In this conference report I shall merely summarize the four papers that were circulated for discussion and also give a short commentary on the keynote address of Dr. Seyyed Hossein Nasr. A report of the discussions and comments made by other participants is outside the scope of this brief report.

\section{Keynote Address: Dr. Nasr-Allah is Peace}

Dr. Nasr set the tone for the first part of the conference by delivering a very profound and philosophical discussion of "peace". He delved into the deepest meanings of the Qur'an and argued that it was a mistake to think of peace as the absence of war or violence. He said that in his understanding peace is, in the most profound sense, the essence of Islam and the most fundamental principle of universal order. He argued that since God is peace, peace was an ever-present presence.

Dr. Nasr suggested that one may conceptualize the essence of peace in concentric circles. The innermost circle represents Man's submission to Allah and is the only means by which Man can make peace with peace (al-salam) in order to be at peace with himself. Man can realize the need for peace, which is intrinsic to fitrah, only through a complete surrender to Allah. The next circle of peace involves making peace with oneself. This entails winning the battle with the nafs, which is called jihad alakbar (the greater struggle). The circles that follow represent the immediate family, the neighborhood, and progressively on to global issues. Dr. Nasr's keynote address and his philosophical interpretation of peace enriched the discussion but also left the participants in an idealistic mode, which precluded discussions of a practical and tactical nature. 


\section{The First Session: Maulana Waheeduddin Khan- Peace and Justice}

Maulana Waheeduddin is a prominent Islamic scholar from India, renowned for his pacifism. True to form, his presentation took a position that was very much at odds with the rest of the participants. At the outset it must be noted that in textual as well as historical analysis, the Maulana's paper was the most substantive one presented at the conference. His arguments were well substantiated from the Qur'an and the Sunnah and were supported by a rich but highly pacifist re-reading of Islamic history.

Maulana Waheeduddin's major thesis was that Muslims must delink the idea of peace from justice. Most of the panelists were of the opinion that peace and justice were inseparable and that often violence and war were consequences of injustices. The Maulana, however, chose to differ. $\mathrm{He}$ argued that positing justice as a precondition to peace would lead to fasad and fitna and unnecessary loss of life, property, and opportunity to develop. He argued that once peace was established (obviously, he understood peace as absence of war and cessation of hostilities), society would have the opportunity to work toward justice. Thus, in the Maulana's mind while peace was necessary for justice, justice was not necessary for peace.

The Second Session: Shaykh Jawadat SaidThe ljtihad on Jihad

Shaykh Jawadat Said, a prominent Islamic scholar and researcher from Syria, led the second session. Like his contemporary from India, Shaykh Said was also inclined toward pacifism, but to a lesser degree than the Maulana. His most important contribution was his ijtihad on jihad. The Shaykh claimed that after forty years of research on the concept of jihad, he had reached the conclusion that the conditions that warranted jihad were few. He raised two issues: Who may declare jihad and upon whom jihad may be declared. In this presentation, however, he limited his discussion to the first issue.

Shaykh Jawadat Said argued that jihad was a collective and not an individual act. He insisted that in his understanding jihad could be declared only by a legitimate ruler of an Islamic political entity. The implications of this position are quite serious for Islamic and other Muslim resistance movements. According to his arguments, for instance, Palestinians may not be able to declare a jihad against Israel. I challenged his position, arguing that this interpretation of jihad made it a privilege rather than an obligation. My understanding of jihad is that it is an obligation, a duty, even an act of 'ibadah. More importantly, for those who view jihad as a purely defensive act-in defense of life, land, property, and faith-jihad would be something forced by an aggressor. 
Perhaps the eminent Shaykh's arguments are more valid for those instances when jihad is used as an offensive instrument as in a preemptive strike or in military interventions. Nonetheless, his contributions were among the most important and telling at the conference.

The Third Session: M.A. Muqtedar KhanPeace and Change

My paper started with the premise that change is absolutely necessary in the Muslim world. We cannot continue to exist between secular tyranny and religious extremism. The protraction of underdevelopment and the presence of multiple levels of conflict between Muslim and nonMuslim states, between Muslim states and within Muslim statesbetween state and society and between secularists and Islamists-clearly indicate that sociopolitical transformation in the Muslim world is absolutely necessary. Thus, since change is necessary, I argued that Muslim intellectuals need to address the issue of engineering peaceful change.

Relying primarily on the Qur'an and a bit on the Sunnah, I problematized the status of peace as an "inherent virtue" desirable for its own sake. Positing justice as a more important value and relying on the Qur'anic injunction that "persecution was worse than killing" (2:217 and $8: 39)$, I argued that peace must be seen as an instrumental value subordinate to the intrinsic value of a just order. Needless to say, the strongest criticism to this position came from Maulana Waheeduddin Khan. Laith Kubba, the discussant, seemed to agree with the philosophical positions advanced in the paper but was curious about the absence of a historical analysis. He also felt that while peace and justice were subjected to philosophically rigorous examination, the same was not extended to the idea of "change" itself.

The Fourth Session: Suhail Hashmi-Just Intervention

Suhail Hashmi is a Harvard Ph.D. who teaches international relations at Mt. Holyoke College. Hashmi's analysis was informed by two normative assumptions: that it is still possible to seriously consider the notion of the ummah as a loosely defined Muslim global political entity and that Quranic principles of peacemaking allow justifiable intervention by Muslims for the protection of Muslims (as in Bosnia or Kashmir) and for peacekeeping between Muslims (as in the Iraq-Kuwait conflict).

Hashmi's presentation demonstrated a sophisticated and contemporarily relevant understanding of the meaning of jihad. Relying on the Qur'an (49:9), he made a convincing case for just interventions on behalf of Muslims as a form of legitimate jihad. His discussion raised interesting issues about multilateralism in the Muslim world and, security cooperation, and conflict resolution between Muslim states based on Islamic principles. 
The presentations generated interesting discussions between the panelists and invited probing questions from the audience. The audience, composed of diplomats, scholars, students, and peace workers, provided interesting insights on theoretical as well as practical issues raised by the panelists. The composition of selected papers showed an interesting balance. The first two panelists were very senior scholars from the Muslim East, and the latter two were younger scholars from the Muslim West. The senior scholars are theologians, while the junior scholars are social scientists in the area of intemational relations. The senior scholars showed greater inclination toward engaging Islam's "textual," past while the younger scholars, working in the relatively free society of the West, showed greater interest in Islam's political present.

In my opinion the conference was a great success. At the very least, it initiated a much needed Muslim-Muslim dialogue. I want to conclude by recalling a suggestion that was made by Mahmood Ayub. He commented that perhaps we should leave the conference with the message that no matter what the differences, Muslims must never resort to violence to resolve disputes and disagreements. Indeed, this remains the most important message that scholars of peace can send to the Muslim world. 